\title{
A calamity of a severe nature: case study - Chennai, India
}

\author{
S. Esther \& M. D. Devadas \\ Anna University, India
}

\begin{abstract}
Chennai is a bustling metropolitan city on the Coast of Tamil Nadu, South India. Although the North East monsoon is due during the months of October and November, it has hardly been a respite to the city and by extension, to the state of Tamil Nadu over the past decade. Chennai has an average rainfall of 16 inches in November. However, 2015 saw a 100-year record break in terms of precipitation over the city. Successive depressions over the Bay of Bengal resulted in two massive spells of rainfall in the city. On November 15, the rainfall recorded in Chennai was 10.5 inches and it peaked on December 1 to 19.3 inches. This was the day that the city went under. A hitherto unknown name for the common man, "Chembarapakkam", which was one of the largest reservoirs for the city, caused terror every time the news flashed that the gates of the reservoir would be opened to release excess water. Mass destruction reigned the following two days with almost every lake, river and canal overflowing, resulting in severe flooding and damage to life and property. What is interesting to note is that the government chose to term it as a "calamity of a severe nature" as opposed to "natural calamity". Simply put, the disaster was largely man made and that due to mismanagement. This paper aims to look at the causes for the flooding and preventive measures to avoid such catastrophes in the future.

Keywords: flood, watershed system, wetlands, marshes, floodplains, drainage systems, runoff, permeability, river banks, encroachments.
\end{abstract}

\section{Introduction}

Chennai is the capital of Tamil Nadu, a south east state in peninsular India. It is a vibrant metro on the eastern coast of the country with the Bay of Bengal to its east. Over a hundred years ago, the city was thickly forested, with rivers and canals 
weaving through. There was an abundance of flora and fauna and a rich wetland ecosystem. However, with rapid globalization and urbanization, the population just over the last 35 years has more than doubled. According to Census 2011, the Chennai Metropolitan Area has a population of 8.6 million. There has been a massive explosion of settlements throughout the city. This unfortunately also meant that the natural environment would rapidly deteriorate, contributing to loss of the natural drainage system of this coastal city. Therefore, the flood that hit the city in November-December 2015 was a disaster waiting to happen.

\section{A record break}

Chennai has an average rainfall of 16 inches in November, which is the peak monsoon season. However, 2015 saw a 100-year record break in terms of precipitation over the city. On Nov 15, the rainfall recorded in Chennai was 10.5 inches while the total rainfall received over the month was 48 inches. It peaked on December 1 to 19.3 inches over a single day. Successive depressions over the Bay of Bengal were pounding the city and the city was not equipped to take this pounding whatsoever.

Chennai has two main reservoirs - Chembarapakkam lake and Puzhal lake. The other major water bodies within the city are the Adyar river, Cooum river and the Buckhingham canal of which the Adyar river and the Cooum river directly take off from the lakes. On November 15, sirens pierced the night, warning residents along the banks of the river to evacuate since the gates of the reservoir were to be opened to release excess water. Consequently, 5000 cusecs of water were released from the lake. Several areas along the river banks were then flooded and this was just a precursor of the flood to come. Another spell of rain started on November 23 which caused the reservoir to be filled up to its limit $-22 \mathrm{ft}$ against its capacity of $24 \mathrm{ft}$.

On November 28th there was another warning issued from the International Weather Forecast about "heavy and very heavy rainfall" with a prediction of $500 \mathrm{~mm}$ rainfall. December 1 saw incessant heavy downpour throughout the day which continued into December 2. On the night of December 1, around 10:00 p.m, the authorities released a massive 30,000 cusecs from the lake, fearing a breach in the reservoir. This was done without warning and caught the hapless residents unaware. The effect was felt in the city roughly three to four hours later where the Adyar river had swollen to 60000 cusecs (fig. 1). It submerged areas along the banks and flooded the city. Power failure and telecommunication failure plunged and isolated areas in the city into islands of despair for the subsequent three days (as shown in figs 2, 3, 4 and 5). What resulted in severe loss in life and property was termed as "a calamity of a severe nature" rather than a "natural calamity", implying that the disaster was man-made and that the scale of the catastrophe could have been lessened with precautions. 


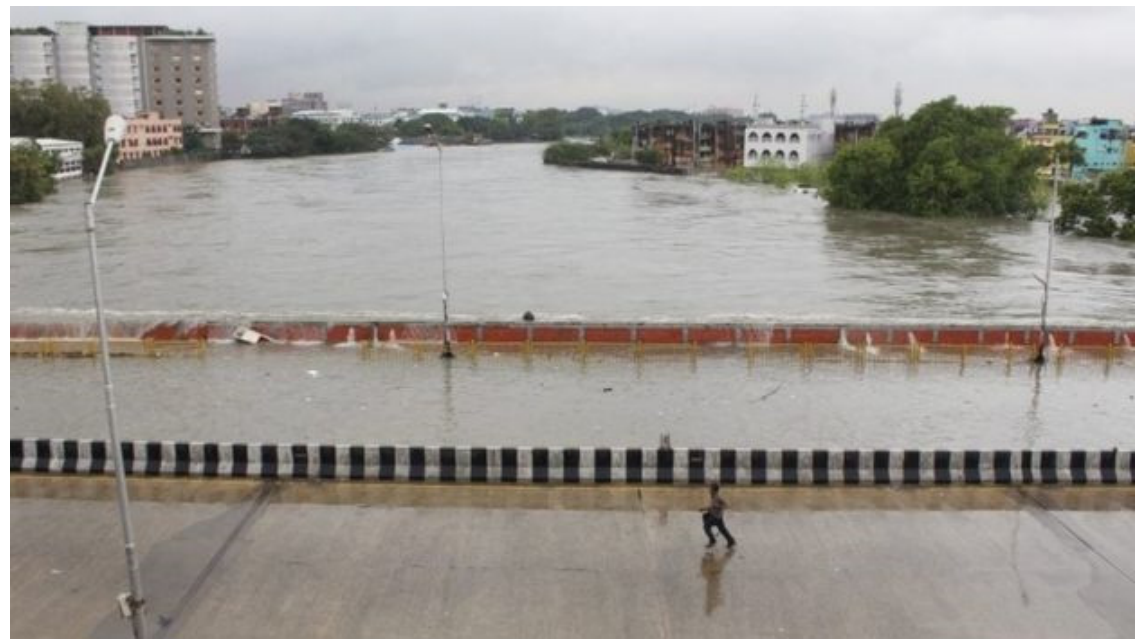

Figure 1: The Adyar river flowing through Chennai rose and broke through bridges in the city (source: http://www.bbc.com/news/world-asiaindia-34992004).

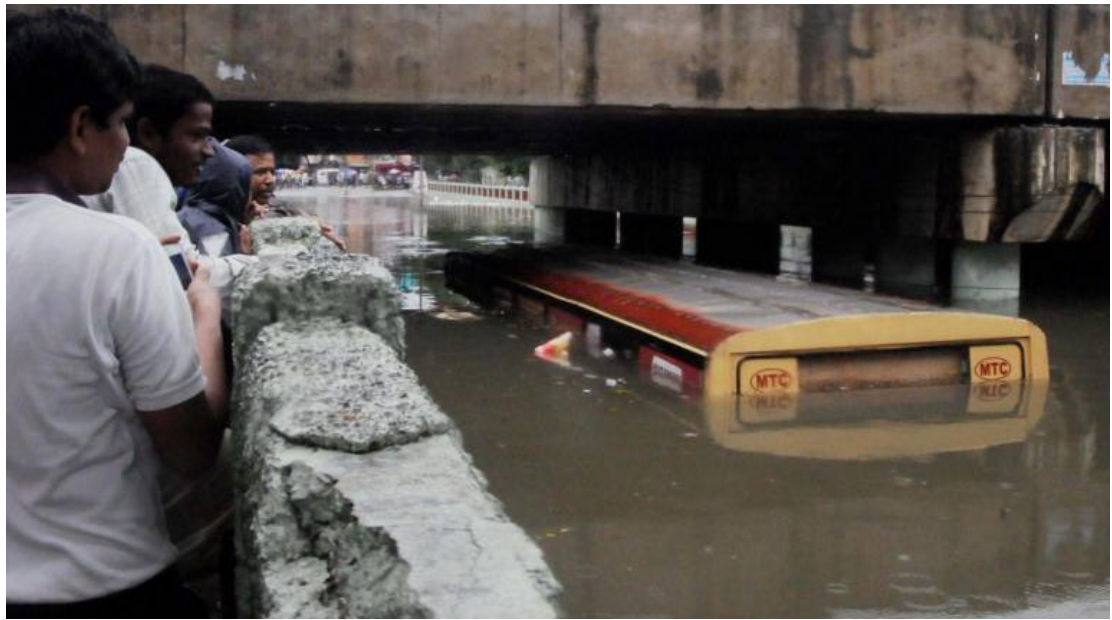

Figure 2: A public transport bus submerged in a flooded subway (source: Daily). 


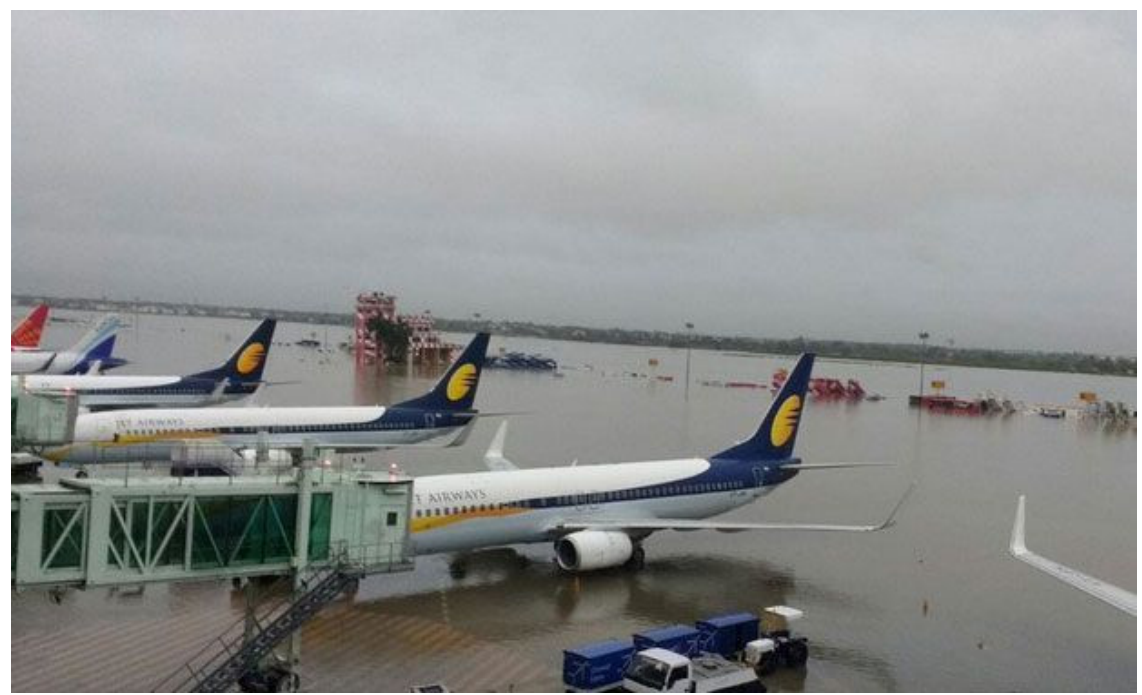

Figure 3: The scene at Chennai airport that was flooded (source: Daily).

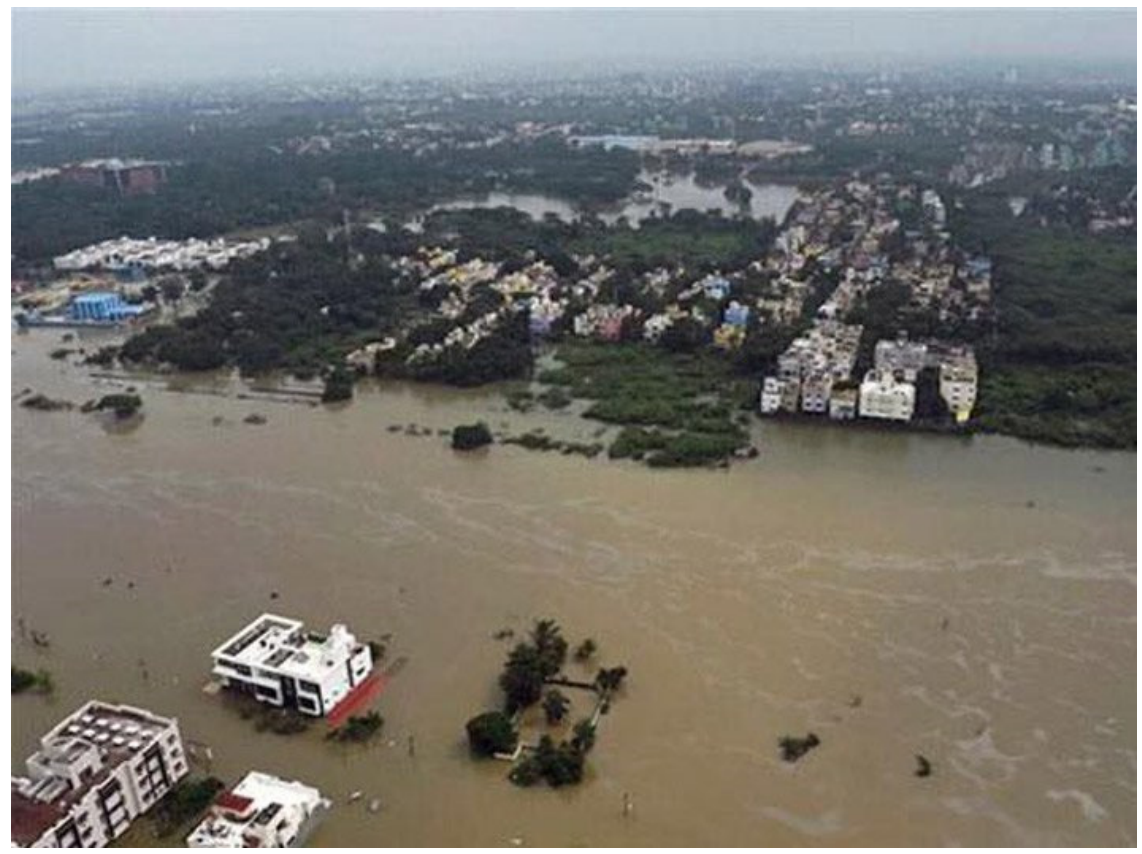

Figure 4: Developments built along the course of water channels reclaimed by water (source: http://www.governancenow.com/news/blogs/ surviving-chennai-floods-came-back-my-apartment-19-days). 


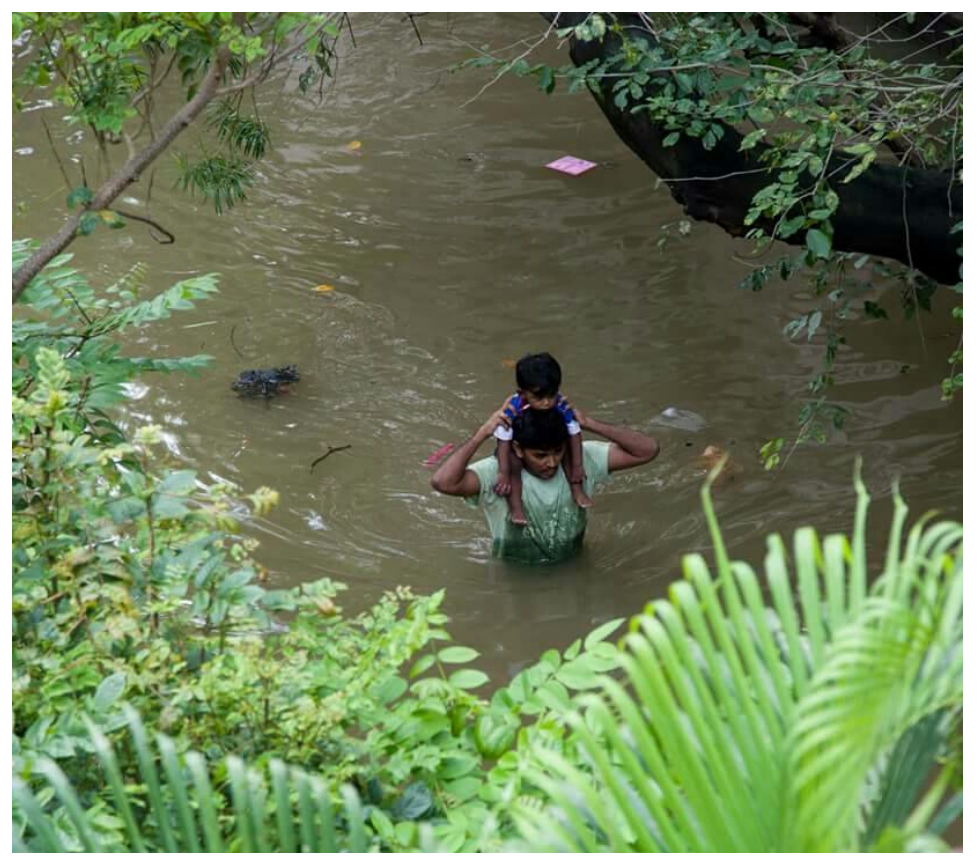

Figure 5: Residents moving out of their neighbourhoods (source: self).

\subsection{Losses incurred}

Chennai has always been referred to as the Detroit of India owing to being a production hub of automobiles. The Associated Chambers of Commerce and Industry in India roughly estimated the loss for automobile production industries alone as Rs. 15000 crores and overall loss in economy of Rs. 20000 crores. Just the insurance sectors faced claims amounting to Rs.500 crores. Lakhs of families were displaced, losing their properties and belongings overnight. The loss of life has been put around 1500, with slums which are mostly encroachments along rivers, and healthcare centres being worst hit.

\section{Causes for flooding}

\subsection{Loss of natural drainage basins}

Prior to urbanisation Chennai had a very effective natural drainage system via southern marshlands. With every new master plan the city receives, that regulates the development within its extents it is observed that the percentage of open areas such as forests, swamps and wetlands have been drastically reduced (fig. 6). The change in land use for the city has faced quite a change. At present, developments have taken over around $90 \%$ of the open swamps. The previous 650 water bodies in Chennai have reduced to a meagre 27. By nature's design, the water naturally drains towards these basins (fig. 7). Had they been retained, areas such as 


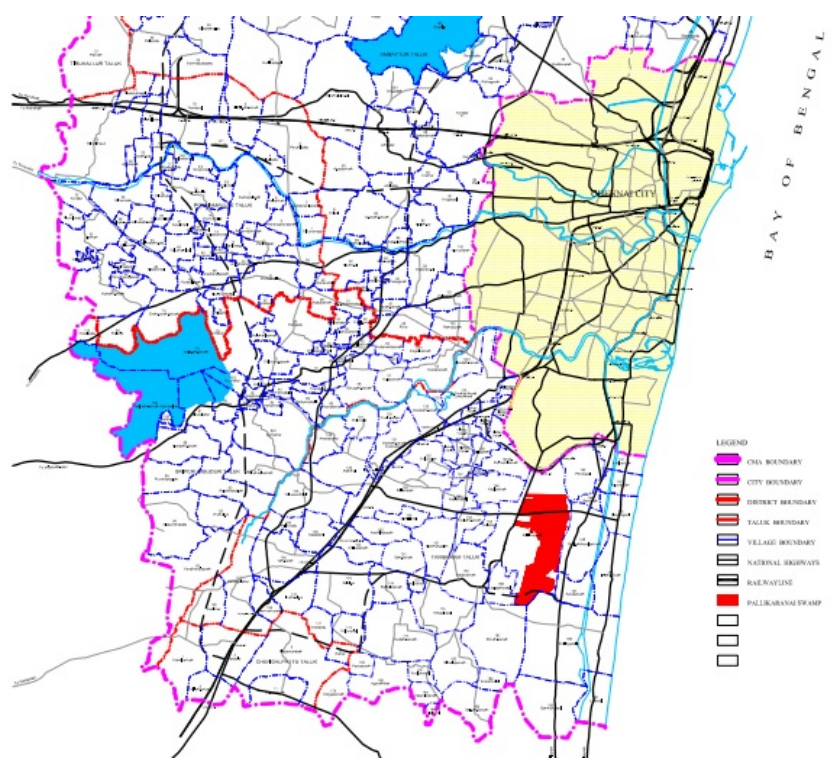

Figure 6: Map of Chennai showing water bodies in blue and marshlands in red (source: Chennai Metropolitan Development Authority, 2008).

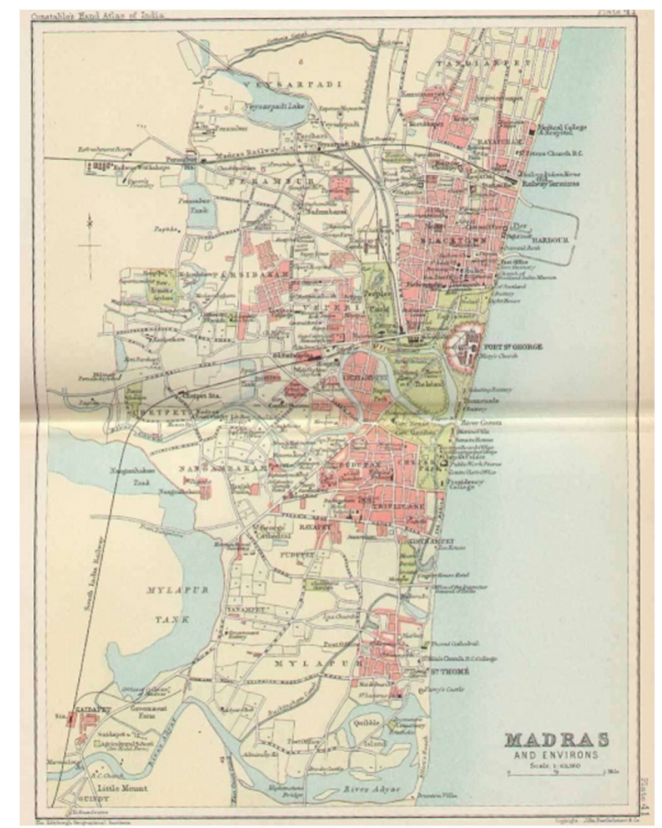

Figure 7: Map of Chennai in 1893 showing many water bodies within the city (source: http://www.transparentchennai.com/576/). 
Velachery and Pallikarnai which were originally wetlands would not have faced the severe flooding that they did. The range of flooding from the main road to the interior blocks and then the swamps further down was between $3 \mathrm{ft}$ to $10 \mathrm{ft}$. These lands that were once considered the outskirts of the city are now within defined city limits with IT industries, dense residential and commercial developments.

\subsection{Illegal encroachments on the path of water drainage}

Around 1.5 lakh illegal structures have come up over the past few years, especially along the water bodies and the dry channels of rivers. They were overlooked by the local authorities for various reasons. However, the monsoon brought to light the severity of such an act. Since they were in the natural path of the water, the floodwaters took their course and these were some of the worst areas affected. Areas such as Manapakkam in Chennai experienced water as high as $15 \mathrm{ft}$.

\subsection{Poor maintenance of man-made drainage systems}

The city's storm water drain systems failed during the monsoon due to being choked severely in several areas. As such, over only one third of the roads have integrated sewers. An integrated system of drains based on actual hydrological calculations needs to be done to equip the city to face such monsoons.

\subsection{Poor maintenance of natural conveyance systems}

The water bodies within the city have been excessively dumped with garbage which hindered the movement of floodwaters at several areas and led to widespread flooding in the adjacent neighbourhoods.

\subsection{Reduction in carrying capacity of water channels}

Studies have proved that over 40 years the width of most of the water channels have now halved to their existing width due to land use change over the years. Consequently, their carrying capacity of water has been reduced.

\subsection{Lack of preparedness for flood}

Huge amounts of water were released from Chembarapakkam lake without warning. This caused loss in life and property that could have been avoided had the warning been timely.

\section{Recommendations: designing and preparing for floods}

\subsection{Comprehensive watershed management}

Comprehensive watershed management study must be undertaken. Streams, Wetlands, marshes and flood plains combine to form watershed systems within the city. They form a system of natural drainage within a region [2]. Firstly they 
need to be preserved as far as possible. Secondly, careful identification of the upper catchment area, water bodies and the conveyance system leading to the sea need to be done for quick and efficient water drainage.

\subsection{Moderate downstream flooding}

Instead of collecting the floodwater and conveying it into the sea after long distances, which would imply collection of flood debris along the path and increasing velocity downstream, the flooding should ideally be discharged locally into planned green pockets and flood basins.

\subsection{Preserve existing ecosystems}

Maintain native soils and vegetation that promote infiltration and increase rainfall retention. Vegetation cover also reduces the energy of rainfall on the soil below, thereby preventing erosion. Although in extreme events, such as severe storms, both natural systems and urban settings will generate runoff. However, the runoff of the former will be reduced since it will absorb the first portion of the rainfall [2].

\subsection{Reduction of impervious surfaces}

Runoff in areas with impervious surfaces will begin almost as soon as the rainfall starts, giving no buffer time for the water to be absorbed into ground at least for the initial spell. Permeability of urban areas is a major factor that can control runoff and lessen the effect of flooding. Green roofs over large developments control run off and mitigate air borne pollution [1].

Table 1: $\quad$ Permeability of water for various surfaces [1].

\begin{tabular}{|l|c|c|}
\hline \multicolumn{1}{|c|}{ Site } & $\begin{array}{c}\text { Bulk } \\
\text { Density }\left(\mathrm{g} / \mathrm{cm}^{3}\right)\end{array}$ & $\begin{array}{c}\text { Permeability } \\
\text { (in } / \mathrm{hr})\end{array}$ \\
\hline Woods & 1.42 & 15 \\
\hline Pasture & 1.47 & 9.9 \\
\hline Single house & 1.67 & 7.1 \\
\hline Lawn & 1.79 & 0.14 \\
\hline Cleared woods & 1.83 & 0.13 \\
\hline Athletic ground & 1.95 & 0.01 \\
\hline Concrete & 2.2 & 0 \\
\hline
\end{tabular}


The natural geography of a region is such that facilitation of natural drainage is accomplished easily. The more the concretization of a region, the greater the runoff. The following are the runoff percentages in different environments [1]. The difference is substantial.

Natural landscape $-10 \%$;

Dense Residential - 30\%;

Urban $-55 \%$.

\subsection{Floodplain restoration}

Floodplains need to be restored along the banks since they are prime regulators of peak floods. The water channels are usually clogged due to unchecked garbage dumping. Timely desilting and maintenance of natural and man-made water conveyance and drainage system will result in efficient and quick drainage of the floodwater from the city that is currently littered with obstructions. The preservation of river banks from erosion and increase in the height of the banks will go a long way in buffering the adjacent neighbourhood [2]. Most of the water channels within the city are quite shallow with a depth of $15 \mathrm{ft}-25 \mathrm{ft}$. Raising the banks of the river will increase the capacity of the channels to carry the water. Natural buffers such as trees slow down the velocity of moving water, by creating a difficult path for the water to flow through and allow for some of it to infiltrate to the soil [1].

\subsection{Preparing for the flood}

Following forecast for continuous heavy rainfall, immediate flood risk assessment should be done. Identification of high risk areas such as the river banks and safe zones within the city should be done and made known to the public. This will help the people to evacuate from high risk zones and stock up for the oncoming disaster. In the case of Chennai, besides saving lives, this would have also prevented loss of property and many automobiles.

\section{Conclusion}

The recommendations suggested in this paper require an inter-disciplinary team of professionals across various sectors working on an integrated system that will seek to intervene in the natural and man-made environments to mitigate the effects of floods during monsoon. The comprehensive team should include hydrologists to work out the drainage network systems, town planners to ensure appropriate allocation of land use, public works authorities to ensure timely desilting of water bodies and at the micro level, include architects and engineers to create green roofs and permeable surfaces for developments. 


\section{References}

[1] Watson, Donald \& Adams Michele, Design for flooding, John Wiley \&Sons, Inc., Hoboken, New Jersey, pp. 71-105, 2011.

[2] Jha, K., Abhas, Bloch, Robin \& Lamond, Jessica, Cities and Flooding, The World Bank, Washington D.C, pp. 207-250, 2012.

[3] The News Minute, http://www.thenewsminute.com/article/urban-planningdenial-why-chennai-gets-unbearably-flooded-and-what-can-be-solution36103

[4] Indian Express, http://indianexpress.com/article/india/india-news-india/ chennai-floods-the-day-city-went-under-who-did-what-and-who-did-not/ 